\title{
Analysis of the Role of Colleges and Universities in Promoting Innovation and Entrepreneurship by Establishing Practice Bases in Characteristic Towns
}

\author{
Tao Wang \\ Shenyang Aerospace University \\ Shenyang, China
}

\begin{abstract}
The proposal of Mass Entrepreneurship and Innovation has put forward new requirements for innovation and entrepreneurship education in colleges and universities. As a bridge between universities and the society, the practice base plays a pivotal role in innovation and entrepreneurship. Firstly, this paper summarizes the problems existing in the course of development of college practice base, and discusses the complementary advantages between college practice base and special towns from the aspects of talent circulation, scientific research transformation, establishment of entrepreneurship platform, and financial support. Therefore, the author analyzes the promotion of innovation and entrepreneurship by establishing practice base in characteristic towns.
\end{abstract}

Keywords—practice base; characteristic town; innovation and entrepreneurship; complementarity; entrepreneurial ecology

\section{INTRODUCTION}

Against the backdrop of the increasing constraints on Chinese resource environment and the gradual weakening of the driving force of factor scale, Premier Li Keqiang of the State Council has lost no time to put forward the Mass Entrepreneurship and Innovation (hereinafter referred to as Double Innovation), which has set off the third wave of national entrepreneurship since the reform and opening up. The Double Innovation puts innovation as the foundation of entrepreneurship and takes entrepreneurship as the driving force for employment, which further stimulates the potential of social innovation and the vitality of mass entrepreneurship.

As an important platform for colleges to realize innovation and entrepreneurship education, the practice base plays an important role in promoting innovation and entrepreneurship. However, there are many problems in the college practice base. For colleges and universities, it is particularly important to choose a suitable practice base construction model to promote entrepreneurship and innovation. There are many coincidences between the essence and development of characteristic towns and the establishment of practice bases in colleges and universities. The establishment of practice bases in colleges and universities based on characteristic towns can not only promote the industrial upgrading and economic development of characteristic towns, but also play a positive role in promoting innovation and entrepreneurship.

\section{PRoBlems IN THE PRACTICE BASE OF COLLEGES AND UNIVERSITIES}

On June 21, 2010, the Outline of the National Medium-and Long-term Education Reform and Development Plan(20102020), which was reviewed and adopted by the Political Bureau of the CPC Central Committee, proposed the task of strengthening the construction and development of laboratories and off-campus practice bases, and affirmed the important role of university practice bases in personnel training and economic development. As an important platform for the realization of teaching practice and scientific research practice in colleges and universities, the practice base complements the theoretical education of colleges and universities with its professional, practical and comprehensive characteristics, which provides a guide for the scientific research of universities. It not only provides a place for students to improve their practical ability and improve their professional literacy, but also expands the channels for teaching practice, scientific research and development, and technology promotion for teachers. For colleges and universities, the practice base is not only an important means for colleges and universities to cultivate innovative and entrepreneurial talents, but also an important driving force to achieve the integration of production, study and research. However, in the course of practice, it is found that there are still many problems in the construction and operation of the college practice bases in China, which results in great differences between the results of the college practice base and the expected goals. On the whole, there are three main problems in the practice base of colleges and universities:

\section{A. Low Degree of Compatibility Between Universities and Enterprises}

As a bridge linking universities and enterprises, the practice base has narrowed the distance between universities and enterprises, and it has a certain ability of talent transportation and scientific research feedback. But in fact, in the process of school-enterprise cooperation, the university and the enterprise as the main body cannot fit perfectly. First of all, universities and enterprises have different goals for talents: colleges and universities hope to cultivate students practical ability, entrepreneurial experience and innovative 
consciousness through practice bases on the platform of school-enterprise cooperation, the main audience is students of all colleges and universities, which are universal; Enterprises pay more attention to their own development and interests, therefore, enterprises have more selective demand for talents. The difference of the orientation of the two subjects leads to the embarrassing situation that the practice base is faced with the non-cooperation of large enterprises and the small enterprises play a small role, which reduces the efficiency of talent transportation. Secondly, there are differences in the research-oriented mechanisms between universities and enterprises. The research of universities is more focused on continuity. The guiding mechanism is more derived from the dominant disciplines of the university. The enterprises pay more attention to the capital transformation of scientific research, and the guiding mechanism comes from the market demand. As a result, the role of the practice base in research feedback between universities and enterprises has been affected.

\section{B. The Management Mode of Practice Base Is Backward}

The management mode of the practice base helps to increase the connection between the university and the society, and provides a guarantee for the practice activities of the practice base. At present, the management of the practice base in colleges and universities mainly follows a more traditional model. Colleges and universities play the role of organizers and managers. The practice activities and research directions are mainly communicated and confirmed by universities and enterprises, and then implemented. This model increases the burden on colleges and universities, not only to organize students, to coordinate teachers and managers, but also responsible for equipment, safety and so on, which undoubtedly reduces the enthusiasm of colleges and universities. In addition, some off-campus practice bases use the venues, equipment, manpower and other resources of company, although they can better achieve the purpose of practical teaching, but for enterprises, the human and material resources occupied by practical activities have not brought direct benefits for the enterprises themselves, which to some extent also frustrated the enthusiasm of the enterprise to participate. It can be seen that the current management mode of the internship base is passive, and the practical activities are practiced for practice, away from the main thrust of practical education.

\section{Insufficient Investment in Practice Funds}

One of the contradictions in the development of colleges and universities is the contradiction between the everexpanding scale of teaching and the shortage of education funds. At present, it is an indisputable fact that college education funds are insufficient. Affected by traditional teaching concepts, many colleges and universities still regard theoretical education as the primary task. When education funds are insufficient to support theoretical education and practical education, they often choose to ignore or even sacrifice the input of practical education to maintain the development of theoretical education. As a result, the educational funds used for practical teaching in many schools have been reduced year by year. Insufficient funding has become one of the bottlenecks restricting the development of the practice base. Although there is a cooperative relationship between universities and enterprises in school-enterprise cooperation, more and more enterprises believe that the current practical education in colleges and universities not only cannot bring direct benefits to enterprises, but also make enterprises bear the burden of accommodation and safety risks. It can be seen that the shortage of practice funds not only limits the scale and quantity of practice base, but also hinders the smooth progress of school-enterprise cooperation, resulting in students' practice time and practice efficiency cannot be guaranteed, thus affecting the quality of practice base.

\section{COMPLEMENTARITY BETWEEN COLLEGE PRACTICE BASES AND CHARACTERISTIC TOWNS}

At present, the problems existing in the practice base of colleges and universities not only affect the development of the practice base itself, but also make the shortcomings of college students' innovation and entrepreneurship education, which affects the cultivation of college students' innovative spirit and the cultivation of entrepreneurial ability. To solve the problem of practice base, colleges and universities need to choose more suitable partners.

The characteristic town is an industrial development platform that relies on the regional characteristic advantage industry, which integrates many factors such as industry, population, city and culture. As the product of new urbanization in China, the characteristic town is an innovation, at the same time, its characteristic industry has the double attribute of inheriting tradition and innovating upgrading. There is a certain coupling mechanism between the development of characteristic town and the construction of college practice base. The practice base of colleges and universities in the construction of characteristic towns not only meets the call of the national Double Innovation policy, but also can effectively solve the dilemmas and problems currently faced by the practice base, and can effectively serve the development of characteristic towns.

\section{A. Complementarity of Human Resources}

A well-off society is talent-oriented. Under the new economic background of China, the Party and the state have repeatedly stressed the importance of talents, and regard the issue of talents as a key issue related to the development of the Party and the state. High-level and high-quality talents have an indispensable role in promoting economic development and social progress.

One of the problems to be solved in the planning process of the characteristic towns is the attraction for innovative talents. How to introduce innovative talents scientifically and continuously has played a decisive role in the industrial upgrading and economic development of the characteristic towns. The characteristic towns have long industrial chain and rich industrial gradient, so the fault-tolerant rate of talent is stronger than that of individual enterprises, and the selection of talent demand is not obvious. As the main body of higher education in China, the employment pressure of college 
graduates has been increasing in recent years. Therefore, there is a strong complementarity in the flow and supply and demand of talent resources, especially innovative talent resources, between characteristic towns and universities. Through the bridge function of the practice base, the specialties of colleges and universities are seamlessly connected with the town industry to form a green channel for talent delivery and supply, which can not only solve the attraction of innovative talents in characteristic towns, but also promote the entrepreneurship and employment of college students.

\section{B. Complementarity of Entrepreneurship Platforms}

The rich variety of enterprises in the characteristic towns and the relatively large number of enterprises provide a platform for college students to start a business. This platform advantage is unmatched by the previous school-enterprise cooperation. Compared with the importance that independent enterprises attach to their own interests, the center of the characteristic town is to promote the development of the industry. Therefore, the development of the enterprise around the characteristic industry of the town is more expansionary. This provides young entrepreneurs with clearer business goals and a relatively fair business environment. At present, the practice bases of colleges and universities mainly focus on the education of innovation and entrepreneurship theory. The opportunity of entrepreneurship for college students comes from the docking of colleges and universities with enterprises or the independent choice according to their own conditions, which is more passive and have weaker goals. Colleges and universities establish practice bases in characteristic towns, relying on the dominant industries of characteristic towns, which help university entrepreneurs to transition from theory to practice, making their entrepreneurial goals more specific, thus increasing the success rate of entrepreneurship.

\section{Complementarity of Scientific Capabilities}

Colleges and universities are one of the producers of technological achievements, and also the main bearers and disseminators of scientific research resources. Benefiting from the support of government funds, the scientific research field of universities will not be restricted by market factors to a certain extent, and the risk factors for scientific research are relatively small. However, the drawback is that the scientific research results of colleges and universities are more biased towards the theoretical results based on experimental data, which leads to the strong scientific research ability of colleges and universities, but the scientific research results lack a sound transformation mechanism. The development of characteristic towns cannot keep up with the pace of the times without the support of scientific research system. How to rely on the integration of scientific research capabilities of advantageous industries to realize the reform and innovation of characteristic towns has become one of the problems that need to be solved in the development of characteristic towns. The practice base set up by colleges and universities in characteristic towns can not only serve as an effective mechanism for the transformation of scientific research achievements in universities, but also an important platform for integrating industries and scientific research in characteristic towns.
Relying on the practice base, the research and industry are organically combined, taking the characteristic industry of the town as the direction of scientific research achievements of the university, and taking the scientific research results of the university as an effective means to promote the development of the characteristic industry, which can guarantee the entrepreneurship of the characteristic towns.

\section{Complementarity of Financial Support}

According to the previous analysis, with the expansion of the scale of colleges and universities, the current practice bases of colleges and universities are faced with the problem of limited development of scale and quantity due to insufficient investment in internship funds, which greatly affects the effect of innovation and entrepreneurship education in colleges and universities. The development of characteristic towns is led by the government to attract investment. Compared with individual enterprises, it pays more attention to long-term development rather than short-term benefits. Colleges and universities set up internship bases in characteristic towns. For the characteristic towns, every innovation and entrepreneurship practice of college students has injected vitality into the characteristic towns, which can obtain both talent reserves and scientific research support. It has reduced the investment in internships in colleges and universities, and at the same time increased the enthusiasm of participating universities and characteristic towns, and better cultivated students' sense of innovation and entrepreneurial ability.

\section{THE ROLE OF UNIVERSITY PRACTICE BASE RELYING ON CHARACTERISTIC TOWNS IN PROMOTING ENTREPRENEURSHIP}

\section{A. Promoting Entrepreneurship Among College Students}

According to the statistics of the Ministry of Education, the number of graduates of ordinary higher education institutions nationwide reached 8.2 million in 2018, an increase of nearly 2 times compared with 2.8 million in 2004. The severity of employment and entrepreneurship can be imagined. Taking the practice base as a bridge to realize the cooperation between universities and characteristic towns, first of all, it provides the direction and platform for college students to start their own business. The practice base established in the characteristic town is more in line with the purpose of their construction, perfecting the innovation and entrepreneurship education of colleges and universities, realizing the close combination of the theory and practice of college students in innovation and entrepreneurship, improving the awareness of innovation and entrepreneurship of college students. It has eased the employment pressure of college graduates. All these provide a quality environment and platform for college students to start their own business. In addition, the establishment of a practice bases in a characteristic town can effectively break through the limitations of different majors in colleges and universities. Since the center of the characteristic town in the development process is in the industry, each link in the industrial chain formed around the characteristic industry is matched by one or more companies. Therefore, the practice base of the 
characteristic town can meet the needs of different majors in colleges and universities for innovation and entrepreneurship education practice.

Therefore, the cooperation between colleges and universities and characteristic towns, through the practice base for the circulation of talents, the demand side and supply side of the docking talents, improve the training and flow mechanism of college entrepreneurial talents, and promote the entrepreneurship of college students.

\section{B. Pulling the Employment of the Population Around the Town}

In the process of development, the characteristic town has a certain radiation force to the surrounding areas and population. The establishment of practice bases in characteristic towns in universities and colleges will help integrate the scientific research capabilities of universities with the industrial potential of towns, promote the development of the industrial chain in characteristic towns, enrich the industrial gradient of characteristic towns, and increase the number of jobs in characteristic towns. This has improved the radiation ability and talent attraction of the characteristic towns to the surrounding areas and the population. And this process will undoubtedly drive the innovation genes and employment enthusiasm of the population around the town. The fair and competitive entrepreneurial environment created by the characteristic towns also provides a guarantee for the employment comfort of the population around the town, and increases the income of the surrounding population by increasing the employment rate. At the same time, the employment rate of the population around the town will also promote the industrial upgrading of the characteristic towns and stimulate the economic growth of the characteristic towns. Therefore, colleges and universities have injected innovative energy and scientific research support into the characteristic towns in the practice base of the construction of the characteristic towns, and realized the characteristic towns to innovate and support entrepreneurship, and promote the healthy development of employment by entrepreneurship.

\section{Building a Sustainable Entrepreneurial Ecosystem}

The construction of the practice base has built a bridge for the cooperation between universities and characteristic towns, and rationally utilized the advantages of characteristic towns and universities to complement each other and build a sustainable entrepreneurial ecosystem. As shown below:

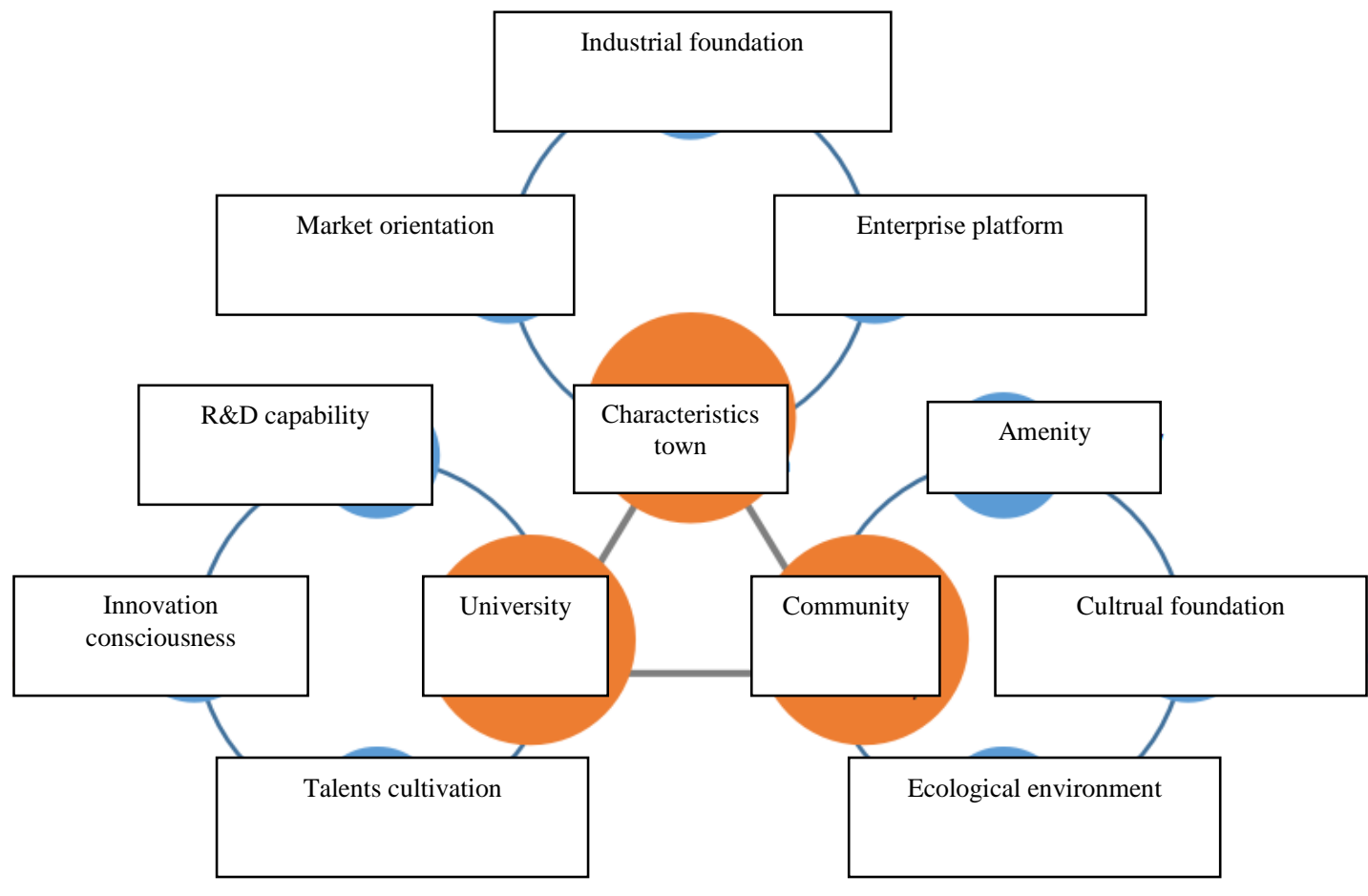

Fig. 1. Entrepreneurial ecosystem based on university-characteristics town.

From a macro point of view, in this set of entrepreneurial ecosystems, the characteristic towns can exert their own advantages and provide an industry-based entrepreneurial platform under the leadership of the market. Universities have injected innovation consciousness and entrepreneurial subjects into the ecosystem, and at the same time, they have provided scientific research support in combination with the industries of characteristic towns. The practice base plays an intermediary role between universities and characteristic towns. Under the guidance of the government, combined with the local ecological environment and cultural foundation of the characteristic town, a supporting living facility is set up for the entrepreneurial main body. It fully embodies the principle of 
government guidance and market leadership in the Double Innovation policy.

From the perspective of individual entrepreneurs, this ecosystem covers innovation and entrepreneurship education, the docking of entrepreneurial platforms, the choice of entrepreneurial direction, and the establishment of entrepreneurial conditions. It provides a channel for the transformation of scientific research results into application capabilities, eliminates the institutional constraints that are not conducive to entrepreneurial innovation and development, creates a fair competitive entrepreneurial environment, and greatly improves the success rate of entrepreneurship, thus stimulating the enthusiasm of the public for innovation and entrepreneurship, and realizes the sustainable development of innovation-entrepreneurshipemployment chain.

\section{CONCLUSION}

The practice base is an important part of the innovation and entrepreneurship education in colleges and universities. This paper analyzes the role of colleges and universities in establishing practice base in characteristic towns to promote entrepreneurship. Firstly, it summarizes the problems and shortcomings of the current practice base in the new economic normal, and explains and analyzes the complementarity between the internship base and the characteristic towns in the supply and demand of talents, the establishment of entrepreneurship platform, the transformation of scientific research results, and the support of internship funds. Finally, according to the complementary mechanism between the practice platform and the characteristic town, the paper expounds the reasons why the practice base of the university based on the characteristic town promotes the formation of entrepreneurship. It provides a new mode of thinking for the construction of practice bases in Colleges and universities, and provides a reference for expanding new channels to promote innovation and entrepreneurship and developing new models to promote innovation and entrepreneurship.

\section{REFERENCES}

[1] MUHAMMAD.K.Mapping Entrepreneurship Ecosystem of Saudi Arabia [J]. World Journal of Entrepreneurship, Management and Sustainable Development, 2013, 9(1): 28-54.

[2] Ai Xunru. Problems and Reflections on the Construction of Offcampus Practice Bases in Colleges and Universities in the New Era[J]. China Forestry Education, 2012, 30(1): 17.

[3] Chen Jianzhong. The Construction of Characteristic Towns Focuses on Planning Characteristic Industries [J]. Zhejiang Economy, 2016 (13): 9-10.

[4] Hua Jucui. Construction and Practice of Practical teaching System for Engineering Majors in Local Universities From the Perspective of Innovation and Entrepreneurship [J]. Modern Education Management, 2017(4): 92-96.

[5] Li Yanli. Thoughts and Countermeasures for the Construction of Innovation Practice Bases in Universities and Colleges in China, 2012, (1): $103-104$

[6] Wu Zhiyun, Wang Liping, Gao Xiaoping. Strengthening the Construction of Practice Bases Inside and Outside Schools [J]. Laboratory Research and Exploration, 2007(5): 95-97.
[7] Xie Wenyuan. On the Characteristics and Problems of College Internship Bases[J]. Higher Education of Science, 2011, (4).

[8] Yang Wei. The Practice of College Students' Creation of Small and Micro Enterprises in Zhejiang ——Taking Zhejiang's "Special Towns" as an Example[J]. China Youth Research, 2016, (4)

[9] Zhang Lingbin, Dong Zhengying. Research on the inter-species synergy effect in the entrepreneurial ecosystem [J]. Ecological Economy, 2014 (5): 75-84. 